\title{
Effect of feeding frequency on the reproductive efficiency of two species of Triatoma with different epidemiological importance
}

\author{
Claudia Rodríguez ${ }^{[1]}$, Patricia Lobbia ${ }^{[2]}$, Julieta Nattero ${ }^{[1]}$, \\ Silvia Catalá ${ }^{[3]}$ and Liliana Crocco ${ }^{[1]}$
}

[1]. Cátedra de Introducción a la Biología, Instituto de Investigaciones Biológicas y Tecnológicas, Facultad de Ciencias Exactas, Físicas y Naturales, Universidad Nacional de Córdoba, Córdoba, Argentina. [2]. Centro de Referencias de Vectores, Pabellón Rawson, Hospital Colonia de Santa María de Punilla, Santa María de Punilla, Córdoba, Argentina. [3]. Centro Regional de Investigaciones Científicas y Transferencia Tecnológica de La Rioja, Anillaco, La Rioja, Argentina.

\begin{abstract}
Introduction: In Triatominae, reproductive efficiency is an important factor influencing population dynamics, and a useful parameter in measuring a species' epidemiological significance as a vector of Trypanosoma cruzi (Chagas, 1909). The reproductive efficiency of triatomines is affected by food availability; hence, we measured and compared the effects of feeding frequency on the reproductive parameters of Triatoma patagonica (Del Ponte, 1929) and Triatoma infestans (Klug, 1934), and the effects of starvation on T. patagonica. Methods: Couples from both species were fed weekly, or every 3 weeks; in addition, females in couples of T. patagonica were not fed. Each couple was observed weekly and reproductive efficiency was assessed on the following parameters: fecundity (eggs/female), fertility (eggs hatched/eggs laid), initiation and end of oviposition, initiation of mating, number of matings/week, and number of reproductive weeks. Relative meal size index (RMS), blood consumption index (CI), and E values (eggs/mg blood) were also calculated. Results: Changes in feeding frequency affected the reproductive parameters of T. patagonica only, with a decrease in fecundity and number of reproductive weeks for those fed every 3 weeks, or not fed. The reproductive period, RMS index, and CI were lower for T. patagonica than T. infestans. However, despite the lower fecundity of T. patagonica, this species required less blood to produce eggs, with an E values of 2 compared to 2.94 for T. infestans. Conclusions: Our results suggest that the differences in fecundity observed between species reflect the availability of food in their natural ecotopes.
\end{abstract}

Keywords: Blood-sucking insect. Chagas disease. Fecundity. Fertility. Triatominae.

\section{INTRODUCTION}

In Latin America, triatomines (Hemiptera: Reduviidae) are recognized vectors of Trypanosoma cruzi, the etiological agent of Chagas disease. Although these hematophagous insects are of wild origin, several species show varying levels of ecological adaptation to human habitats ${ }^{1,2}$, and this trait is relevant in characterizing the epidemiological importance of these species ${ }^{1}$.

Of the 140 species in this subfamily ${ }^{3}, 18$ occupy wild habitats in Argentina, in addition to intradomicile and peridomicile environments ${ }^{4}$. Triatoma infestans is one species that has successfully adapted to human habitats. This primary vector has a wide distribution in southern South America, and is the most epidemiologically important species in Argentina, colonizing

Address to: Dra Claudia S. Rodríguez. Cátedra Introducción a la Biología/ Facultad de Ciencias Exactas, Físicas y Naturales/UNC. Av. Vélez Sarsfield 299, piso 5, X5000JJC Córdoba, Argentina.

Phone: $54351433-2100$ ext. 248.

e-mail: claudiarodriguez@efn.uncor.edu

Received 15 May 2014

Accepted 8 July 2014 intradomicile and peridomicile environments, where it is associated with birds, and occasionally mammals ${ }^{4}$. In addition, Triatoma infestans has been shown to have a significant level of natural infection with T. $c r u z i^{1,5,6}$.

Triatoma patagonica occupies wild and peridomestic habitats, and has only been reported in Argentina to date, with its southernmost distribution limited to the Chubut province of Patagonia $^{7}$. This secondary vector ${ }^{8}$ has been shown to establish significant colonies in peridomestic ecotopes ${ }^{9}$ where it feeds on both birds and mammals ${ }^{7}$, and a few instances of intradomicile colonization have been recorded ${ }^{10,11}$. Triatoma infestans and T. patagonica can colonize different peridomestic structures, feeding on both birds and mammals; in rural areas of Argentina, chicken coops are the most common of such structures ${ }^{12,13}$, and thus, in these habitats T. infestans feeds predominantly on chickens, as opposed to dogs or goats ${ }^{12,14}$.

The reproductive efficiency of a species is strongly associated with its potential to colonize or recolonize a habitat; thus, information on its effects on population dynamics may help to determine the epidemiological significance of different triatomine species ${ }^{15,16}$. Reproductive efficiency, as determined by parameters related to fecundity and fertility ${ }^{15,17}$, may vary between species of triatomines; however, within species, 
this variation is significantly affected by factors such as environment (temperature), physiology (insect age, and gonadotrophic cycle status) and food (volume, quality, and availability ${ }^{18}$. Food availability in the wild varies and insects may feed daily or undergo prolonged fasting, with each species having a critical feeding frequency at which reproductive parameters begin to be affected ${ }^{19}$.

In adult female triatomines, blood meals are essential for egg production, as they stimulate endocrine regulation of ovarian development ${ }^{20}$. However, females that have high nutritional reserves from the fifth-instar nymph stage can undergo the first cycle of egg production without feeding ${ }^{20}$. This phenomenon, known as autogeny, has been described for several triatomine species $^{21-23}$, including T. infestans ${ }^{23}$ and T. patagonica ${ }^{24}$. However, reproductive parameters under fasting conditions for the latter have yet to be fully described.

Abalos ${ }^{25}$ has questioned whether T. patagonica could replace T. infestans as a permanent host of T. cruzi in intradomiciliary environments in southern Argentina. Considering that these species, which have a different epidemiological importance, coexist in peridomiciliary habitats, the objective of this work was to compare the effects of different food supply frequencies and starvation conditions on their reproductive parameters.

\section{METHODS}

Triatoma patagonica and Triatoma infestans were supplied by the Coordinación Nacional de Control de Vectores (Córdoba province, Argentina). These insects were originally obtained from chicken coops in the San Luis and La Rioja provinces (Argentina). First-generation insects were reared from eggs in our laboratory and maintained under controlled temperature $\left(26 \pm 1^{\circ} \mathrm{C}\right)$ and relative humidity $(60 \pm 10 \%)$, and a photoperiod of 12:12h (light: dark). Groups of 15 insects were kept in cylindrical $\left(500 \mathrm{~cm}^{3}\right)$ glass bottles covered with nylon mesh and containing vertically folded paper to allow insects' access to food and to avoid excess humidity. Triatomines were allowed to feed for $30 \mathrm{~min}$ on an immobilized pigeon (Columba livia Gamelin) placed on a plastic box. First-instar nymphs of each species were divided into 2 groups and fed either weekly, or every 3 weeks, from the nymphal to the adult stage.

Once triatomines had reached the adult stage (between August and September), couples from each group, for both species, were placed in separate glass bottles until both insects died. The 4 groups were defined as follows: G1: 13 couples of T. patagonica fed once a week; G2: 13 couples of T. patagonica fed every 3 weeks; G3: 10 couples of $T$. infestans fed once a week; and G4: 13 couples of $T$. infestans fed every 3 weeks.

In addition, an autogenic group comprised 13 couples of T. patagonica, which were fed every 2 weeks throughout the nymphal stage, and then females were not fed, and males were fed once a week, for the adult stage.

\section{Reproductive parameters}

Couples were observed weekly until females died, and the following data were recorded: initiation and end of oviposition; initiation of mating; matings per week (determined by observation of spermatophores); reproductive weeks, fecundity (number of eggs laid/female); age-specific fecundity $\left(\mathrm{m}_{\mathrm{x}}=\right.$ mean eggs/female/week); and fertility (number of eggs hatched/number of eggs laid), calculated as: (number of eggs hatched/total eggs) $\times 100$. The length of the adult stage (days) for females was also recorded. Eggs were stored in Eppendorf tubes until nymphs hatched.

\section{Relationships between feeding frequency and reproductive parameters}

Females were weighed on the day of imaginal molt, and before and after each feeding event, to calculate the amount of blood consumed. The relative meal size index $(\mathrm{RMS}=$ meal size/insect weight before feeding) was calculated to allow comparison between species ${ }^{26}$.

The blood consumption index (CI) was calculated for each group as per Catalá et al. ${ }^{27}$ using the following formula: $\mathrm{CI}=[(\mathrm{Bi}+\mathrm{F})-\mathrm{Be}] / \mathrm{T}$, where $\mathrm{Bi}$ is blood in the stomach at moulting; $\mathrm{F}$ is the weight of ingested food (sum of intakes); $\mathrm{Be}$ is blood in the stomach after the last feeding event; and $\mathrm{T}$ is the duration of the adult stage (days). Blood contained in the stomach (BCS) was calculated using the following equations: $\mathrm{BCS}=-69.76+0.54 \mathrm{x}$ and $\mathrm{BCS}=-14.07+0.32 \mathrm{x}$, as described by Catalá de Montenegro ${ }^{28}$ for $T$. infestans and Nattero et al. ${ }^{29}$ for T. patagonica, respectively. E values were calculated as follows: [total number of eggs/(initial female weight $\times$ amount of blood ingested) $] \times 1,000^{30}$.

All weight measurements were performed using a Mettler Toledo precision balance (PG203-S) to a level of $0.001 \mathrm{~g}$.

\section{Data analysis}

Means and standard deviations were calculated for each variable. If data for variables did not show normal distribution or homogeneity of variance, as analyzed by the KolmogorovSmirnov and Levene's tests respectively, groups were compared using a non-parametric Mann-Whitney test (statistical index U) or Kruskal-Wallis one-way analysis of variance (statistical index U). Spearman's correlation coefficient $\left(r_{s}\right)$ was used to evaluate correlations between reproductive parameters and feeding behavior for each species. Percentages were compared using Fisher's test. A p-value $<0.05$ was considered statistically significant.

\section{RESULTS}

Only couples in which females laid eggs were considered in the analysis of reproductive efficiency and feeding behavior. All T. infestans females ( $\mathrm{n}=23 / 23$, groups G3 and G4) and $65.38 \%$ ( $\mathrm{n}=17 / 26$, groups G1 and G2) of T. patagonica females laid eggs at least once, and data from these groups was further examined (Table 1).

Female longevity was similar within each species for both feeding regimens. However, T. patagonica females had a significantly shorter lifespan than $T$. infestans females with a mean age of $77.92 \pm 64.81$ days compared to $316.60 \pm 95.58$ days $(\mathrm{H}=33.91, \mathrm{p}<0.001)$. 
TABLE 1 - Reproductive parameters for Triatoma patagonica and Triatoma infestans females with different feeding regimens (G1 and G3: fed weekly; G2 and G4: fed every 3 weeks).

\begin{tabular}{|c|c|c|c|c|c|c|}
\hline & \multicolumn{3}{|c|}{ Triatoma patagonica } & \multicolumn{3}{|c|}{ Triatoma infestans } \\
\hline Initiation of oviposition (days) & $31.33 \pm 17.65$ & $23.25 \pm 6.75$ & $33.5(0.06)$ & $6.22 \pm 7.08$ & $4.80 \pm 10.04$ & $26.5(0.36)$ \\
\hline Fecundity (eggs/female) & $72.11 \pm 66.0$ & $20.50 \pm 14.48$ & $15.0(0.04)$ & $183.3 \pm 118.33$ & $132.61 \pm 113.21$ & $41.1(0.14)$ \\
\hline Initiation of mating (days) & $31.33 \pm 17.65$ & $23.25 \pm 6.75$ & $43.0(0.87)$ & $6.22 \pm 7.08$ & $4.80 \pm 10.04$ & $32.0(0.10)$ \\
\hline Number of matings & $10.0 \pm 7.14$ & $4.12 \pm 2.85$ & $24.5(0.26)$ & $33.61 \pm 18.24$ & $26.4 \pm 9.22$ & $56.0(0.79)$ \\
\hline Fertility (\%) & $72.1 \pm 66.0$ & $20.5 \pm 14.5$ & $18.0(0.24)$ & $56.3 \pm 22.3$ & $66.7 \pm 34.9$ & $44.5(0.30)$ \\
\hline
\end{tabular}

$\overline{\mathbf{X}} \pm$ SD: mean \pm standard deviation; $\mathbf{n}$ : number of insects; $\mathbf{U}$ : statistical index of Mann-Whitney test.

\section{Reproductive parameters}

Fecundity was significantly higher in $T$. patagonica females fed once a week (G1) than those fed every 3 weeks (G2; p $<0.05$; Table 1); however, there were no significant differences between feeding frequency for other reproductive parameters measured for this species (Table 1). For T. infestans there were no significant differences between groups for any of the reproductive parameters measured (Table 1).

Oviposition $(\mathrm{H}=16.62$, d.f. $=3, \mathrm{p}=0.0008)$ and mating $(\mathrm{H}=16.17$, d.f. $=3, \mathrm{p}=0.01)$ began earlier in T. patagonica than T. infestans; however, fecundity and reproductive weeks were higher for $T$. infestans $(\mathrm{H}=17.62$, d.f. $=3, \mathrm{p}=0.005$ and $\mathrm{H}=25.58$, d.f. $=3, \mathrm{p}<0.0001$ for fecundity and reproductive weeks respectively).

Of all couples observed, $88.2 \%(\mathrm{n}=15 / 17)$ of $T$. patagonica and $78.3 \%(\mathrm{n}=18 / 23)$ of $T$. infestans mated at least once, with no difference between species ( $p=0.209$, Fisher exact test). The mean mating number was significantly higher for T. infestans than T. patagonica $(\mathrm{H}=7.94$, d.f. $=3, \mathrm{p}=0.04)$, and the fertility rate was below $62.0 \%$, with no differences between species $(\mathrm{U}=132.00, \mathrm{p}=0.307$; Table 1).

In T. patagonica reproductive activity began at week 2 and week 3 for G1 and G2 respectively, with the maximum reproductive effort $\left(\mathrm{m}_{\mathrm{x}}\right)$ recorded at week 6 for $\mathrm{G} 1$ and week 4 for $\mathrm{G} 2$ (mean $\mathrm{m}_{\mathrm{x}} 9.24 \pm 6.18$ and $5.90 \pm 4.52$ eggs/ female/week for G1 and $\mathrm{G} 2$ respectively) with no significant difference between groups $(U=24.00, p=0.24)$. From week 7 for $\mathrm{G} 1$ and week 13 for $\mathrm{G} 2, \mathrm{~m}_{\mathrm{x}}$ values began to decrease until females stopped laying eggs; however, there were a number of additional reproductive peaks for G2 (Figure 1A). In T. infestans, reproductive activity began at week 2 for both groups, and mean $\mathrm{m}_{\mathrm{x}}$ values did not differ significantly between groups $(\mathrm{U}=36.00, \mathrm{p}=0.07)\left(\right.$ mean $\mathrm{m}_{\mathrm{x}} 7.43 \pm 4.51$ and $4.56 \pm 3.91$ eggs/female/week for G3 and G4 respectively). The maximum reproductive effort for this species was recorded at the end of the reproductive period, at week 41 for G3 (26 eggs/ female) and at week 65 for G4 (32 eggs/female; Figure 1B).
For both species, the number of matings positively correlated with fecundity $\left(\mathrm{r}_{\mathrm{s}}=0.64, \mathrm{p}=0.004\right.$ and $\mathrm{r}_{\mathrm{s}}=0.56, \mathrm{p}=0.006$, for T. infestans and T. patagonica respectively). For T. infestans females, there was also a correlation between initiation of oviposition and mating $\left(\mathrm{r}_{\mathrm{s}}=0.53, \mathrm{p}=0.013\right)$.

Initiation of oviposition (20.23 \pm 8.2 days), first mating $(14.33 \pm 3.70$ days $)$, and fertility $(53.75 \pm 40.85 \%)$ for the autogenic group of $T$. patagonica (autogenic group) showed similar values to those for $\mathrm{G} 1$ and $\mathrm{G} 2(\mathrm{H}=3.78, \mathrm{p}=0.15$; $\mathrm{H}=3.52, \mathrm{p}=0.17$ and $\mathrm{H}=5.90, \mathrm{p}=0.052$ respectively). However, the number of reproductive weeks $(2.92 \pm 1.75)$ of the autogenic group was lower than that for other groups $(H=9.07, p=0.01)$, and fecundity (16.38 \pm 7.81 eggs per female) was significantly lower than $\mathrm{G} 1$ and similar to $\mathrm{G} 2(\mathrm{H}=9.57, \mathrm{p}=0.008)$.

\section{Relationships between feeding frequency and reproductive parameters}

Only G1 and G2 groups were analyzed in terms of relationships between feeding frequency and reproductive parameters.

The weight at moulting of the $T$. patagonica $\mathrm{G} 1$ group was higher than that of G2; however, there were no significant differences between the G3 and G4 groups of $T$. infestans. For both species, the volume of blood ingested in the adult stage was similar for females fed weekly or every 3 weeks (Table 2). T. infestans females had a higher RMS index and blood CI than T. patagonica, when fed weekly $(\mathrm{U}=10.00, \mathrm{p}=0.007$ and $\mathrm{U}=5.00, \mathrm{p}=0.002$ for RMS and CI, respectively) and every 3 weeks $(U=0.00, p=0.006$ and $U=11.00, p=0.003$ for RMS and CI, respectively; Table 2).

For T. patagonica, oviposition began before the first feeding event for $33.3 \%$ and $62.5 \%$ of females for G1 and G2 respectively; however, for $T$. infestans, no females laid eggs without being fed at least once.

For T. patagonica females, there were no statistically significant differences for $\mathrm{E}$ values in relation to feeding frequency, and standard deviations were high. However, these 

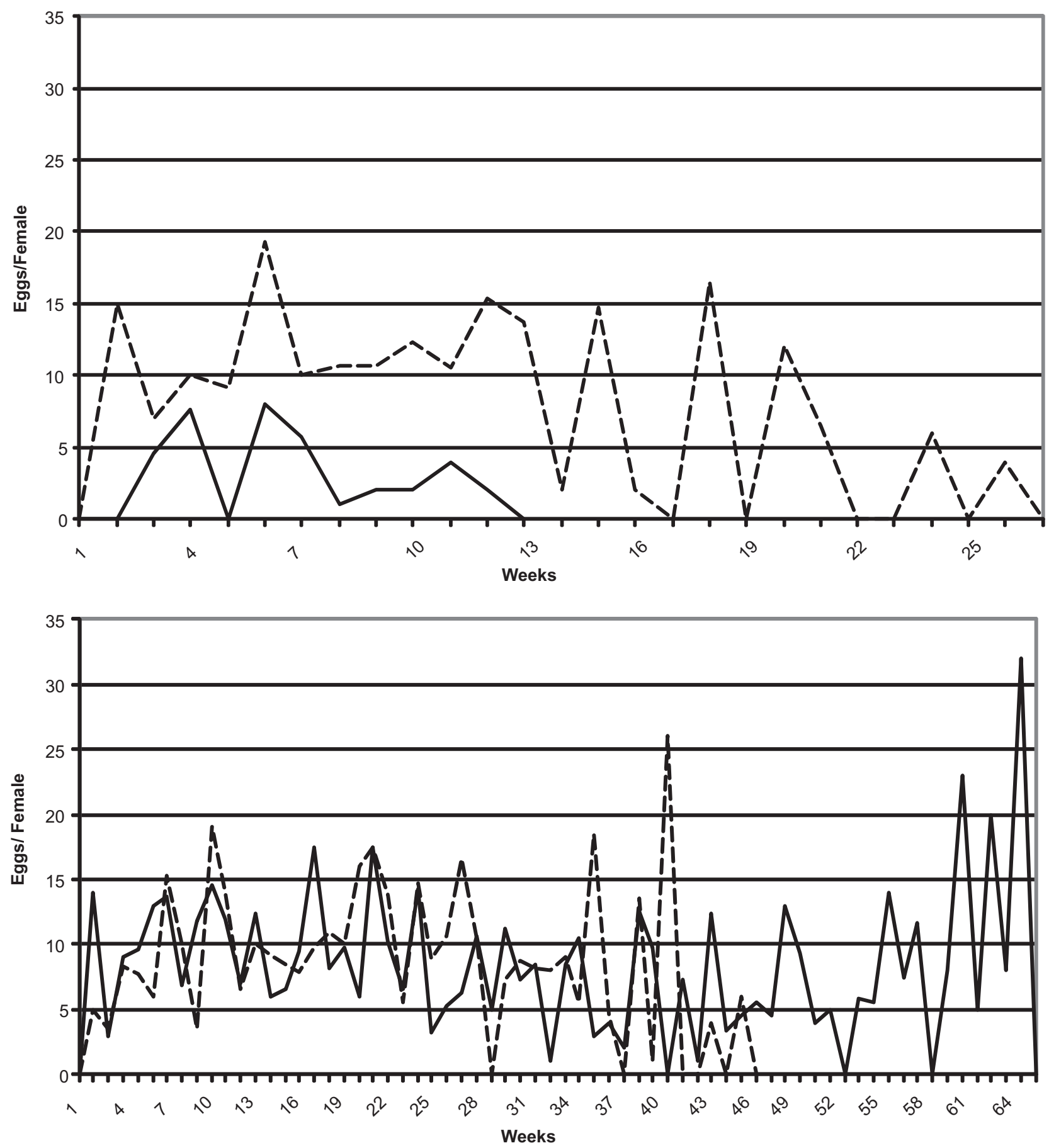

FIGURE 1 - Age-specific fecundity curves $\left(\mathrm{m}_{\mathrm{x}}\right)$ for $(\mathrm{A})$ Triatoma patagonica and (B) Triatoma infestans females with different feeding regimens. Dotted lines: groups fed weekly (G1 and G3); Continuous lines: groups fed every 3 weeks (G2 and G4).

E values were significantly higher than those recorded for both groups of $T$. infestans females $(\mathrm{H}=20.47$, d.f. $=3, \mathrm{p}=0.0001$; Table 2).

For both species, the volume of blood ingested during the adult stage correlated positively with fertility $\left(\mathrm{r}_{\mathrm{s}}=0.62\right.$, $\mathrm{p}=0.030$ for $T$. patagonica and $\mathrm{r}_{\mathrm{s}}=0.60, \mathrm{p}=0.05$ for T. infestans) and reproductive weeks $\left(\mathrm{r}_{\mathrm{s}}=0.85, \mathrm{p}=0.0003\right.$ for T. patagonica and $\mathrm{r}_{\mathrm{s}}=0.54, \mathrm{p}=0.05$ for $T$. infestans).

\section{DISCUSSION}

Feeding has a direct effect on the reproductive efficiency of triatomines. Variations in reproductive parameters within species relate to food availability, quality, and nutritional status $^{18}$, whereas differences between species may be due to the relationship between reproductive behavior and the insects' 
TABLE 2 - Amount of blood ingested, relative meal size index, blood consumption index and E values for Triatoma patagonica and Triatoma infestans (G1 and G3: fed weekly; G2 and G4: fed every 3 weeks).

\begin{tabular}{|c|c|c|c|c|c|c|}
\hline & \multicolumn{3}{|c|}{ Triatoma patagonica } & \multicolumn{3}{|c|}{ Triatoma infestans } \\
\hline Weight at molting (mg) & $186.1 \pm 30.6$ & $146.5 \pm 45.2$ & $33.5(0.009)$ & $247.5 \pm 56.4$ & $218.2 \pm 60.2$ & $45.0(0.21)$ \\
\hline Blood ingested (mg) & $439.5 \pm 350.5$ & $116.0 \pm 114.4$ & $16.0(0.09)$ & $2071.7 \pm 798.5$ & $2192.6 \pm 1221.0$ & $64.0(0.95)$ \\
\hline CI (mg/day) & $3.35 \pm 1.47$ & $2.37 \pm 2.07$ & $18.0(0.14)$ & $7.08 \pm 2.14$ & $6.13 \pm 2.42$ & $39.0(0.19)$ \\
\hline E value (eggs/mg blood) & $1.58 \pm 1.25$ & $2.40 \pm 4.49$ & $9.0(0.16)$ & $0.50 \pm 0.39$ & $0.21 \pm 0.09$ & $24.0(0.01)$ \\
\hline
\end{tabular}

$\overline{\mathrm{X}} \pm$ SD: mean \pm standard deviation; $\mathbf{n}$ : number of insects; $\mathbf{U}$ : statistical index of Mann-Whitney test; RMS: relative meal size index; CI: consumption index.

natural habitat ${ }^{15}$. Consensus has not yet been reached in terms of the quality of ingested blood, with some species showing greater reproductive efficiency when fed on mammals or birds $^{15,17,29}$, but other species not ${ }^{15}$; variability has even been shown between different studies of the same species ${ }^{15,29}$. For this reason, our results are discussed in the context of other studies using the same food source. The reproductive efficiency of T. infestans females does not appear to be affected by feeding frequency, as there were no differences between groups for any reproductive parameters. However, the reproductive efficiency of the secondary vector $T$. patagonica appears to be sensitive to feeding frequency, as fecundity, reproductive weeks, and blood consumption, were lower in females fed every 3 weeks than those was fed weekly. Similarly, Zeledón et al. ${ }^{21}$ and Cabello et al. ${ }^{19}$ reported an increase in fecundity with increased feeding frequency for Triatoma dimidiata and Rhodnius neivai.

On the other hand, the fact that $T$. patagonica that were starved had similar fecundity and reproductive week values to those of females fed every 3 weeks suggests that this is close to the critical fasting limit for this species in terms of reproductive parameters.

Females of $T$. patagonica began to lay eggs earlier than T. infestans. This may be related to the stimulatory effects of mating on oviposition ${ }^{20}$, as females of this peridomiciliary species copulated earlier than those of the domiciliary species. In $T$. infestans ${ }^{31}$ and other domiciliary triatomine species like Panstrongylus megistus ${ }^{32}$ and Triatoma brasiliensis ${ }^{13}$, virgin females were found to begin laying eggs later than those that had copulated. Accordingly, Carrizo ${ }^{24}$ reported that virgin females of $T$. patagonica fed fortnightly began oviposition at $38.2 \pm 14.4$ days, later than that recorded here.

Fecundity and reproductive weeks were also different between species, with values for both higher in T. infestans than $T$. patagonica. However, the fecundity values under starvation for $T$. patagonica seen in this study were higher than those reported by Noriega ${ }^{20}$ for $T$. infestans under similar conditions. This may be an advantageous characteristic in T. patagonica, allowing it to lay many eggs prior to first feeding in a peridomicile habitat where food availability is variable. For both species, fertility rates were similar; however, they were lower than values previously recorded for these species ${ }^{7,26,33}$, as well as other peridomiciliary and domiciliary species ${ }^{7,34,35}$ fed on birds blood. This decrease might be due to excessive insect manipulation during the performance of experiments, and is in agreement with results reported by Tolesano et al. ${ }^{36}$ for T. infestans.

Reproductive efficiency in terms of fecundity was compared between species by calculating indices relating egg production to blood consumption. Although T. patagonica laid fewer eggs and had a lower RMS than T. infestans, they consumed a smaller volume of blood daily (CI) and were more efficient in converting blood into eggs (E values), producing approximately 2 eggs per mg blood ingested. To produce a similar number of eggs, T. infestans required approximately $4 \mathrm{mg}$ of blood when fed weekly. The E values obtained in this work are similar to those reported by Guarneri et al. ${ }^{15}$ for other domiciliary and peridomiciliary species. These authors indicated that differences in $\mathrm{E}$ values between species reflect the food availability of the insects' natural ecotopes.

In the natural environments of triatomine species, there are a number of interacting factors that cannot be reproduced in the laboratory, such as behavioral responses to the environment and to different food sources, and genetic variability of populations ${ }^{34,37}$. Hence, although it is difficult to extrapolate the data presented here directly to populations developing in natural environments, our results do indicate trends in the behavior of these species relative to these environments.

Our comparison of the reproductive efficiency of these two species with different epidemiological importance indicates that, unlike domiciliary species, peridomiciliary species such as $T$. patagonica allocate a greater percentage of ingested blood to reproduction than maintenance. This characteristic may be related to the environmental conditions under which this species develops. Peridomiciliary species live in unstable ecotopes, and form small scattered colonies with infrequent access to food sources, whereas domiciliary species live in more stable ecotopes in high densities and with frequent food access. 


\section{ACKNOWLEDGMENTS}

We thank the Coordinación Nacional de Control de Vectores (Santa María de Punilla, Córdoba, Argentina) for providing specimens of T. patagonica and T. infestans; Walter Almirón, Gabriel Manrique, and Jorge Rabinovich for their contribution to the development of experiments; and Jorgelina Brasca for language editing.

\section{CONFLICT OF INTEREST}

The authors declare that there is no conflict of interest.

\section{FINANCIAL SUPPORT}

This study was funded by the Secretaría de Ciencia y Técnica, Universidad Nacional de Córdoba (05/1554).

\section{REFERENCES}

1. Zeledón R. Vectores de la enfermedad de Chagas y sus características ecofisiológicas. Interciencia 1983; 8:384-395.

2. Noireau F, Carbajal de la Funte AL, Lopes CM, Diotaiuti L. Some considerations about the ecology of Triatominae. An Acad Bras Cienc 2005; 77:431-436.

3. Schofield CJ, Galvão C. Classification, evolution and species group within the Triatominae. Acta Tropica 2009; 110:88-100.

4. Canale DM. Actualización de la biología de triatominos. Medicina 2000; 6:14-15.

5. Gürtler RE, Cohen JE, Cecere MC, Chuit R. Shifting host choices of the vector of Chagas disease, Triatoma infestans, in relation to the availability of host in houses in North-West Argentina. J Apl Ecol 1997; 3:699-715.

6. Schofield CJ, Jannin J, Salvatella R. The future of Chagas disease control. Trends Parasitol 2006; 22:583-588.

7. Carcavallo RU, Martínez A. Biología, ecología y distribución geográfica de los triatominos americanos. In: Carcavallo RU, Rabinovich JE, Tonn RJ, editors. Factores biológicos y ecológicos en la enfermedad de Chagas). Buenos Aires, Argentina: CPEHS OPC/OMS, Ministerio de Salud y Acción Social; 1985. p. 149-208.

8. Canale DM. Triatominae: Vinchucas. In: Salomón OD, editor. Artrópodos de Interés Médico en Argentina, Serie Enfermedades Transmisibles Fundación Mundo Sano. Buenos Aires, Argentina: Fundación Mundo Sano; 2005. p. 37.

9. Wisnivesky-Colli C, Vezzani D, Pietrokovsky SM, Scurti H, Iriarte J. Ecological characteristics of Triatoma patagonica at the southern limit of its distribution (Chubut, Argentina). Mem Inst Oswaldo Cruz 2003; 98:1077-1081.

10. Ferrero A, Visciarelli EC, Torno O, Costamagna SR. Presencia de Triatoma patagonica en viviendas humanas en la ciudad de Río Colorado, Provincia de Río Negro. Rev Soc Entomol Argent 1999; 58:79-84.

11. Giraldez E, López Ureta MP, Nepote M. Colonización domiciliaria por T. patagonica en el departamento San Cristóbal, provincia de Santa Fe. Rev Méd Rosario 2009; 75:38.

12. López A, Crocco L, Morales G, Catalá S. Feeding frequency and nutritional status of peridomestic populations of Triatoma infestans from Argentina. Acta Tropica 1999; 73:275-281.

13. Cecere MC, Vazquez-Prokopec GM, Gürtler RE, Kitron U. Reinfestation sources for Chagas disease vector, Triatoma infestans, Argentina. Emerg Infect Dis 2006; 12:1096-1102.
14. Gürtler RE, Ceballos LA, Ordoñez-Krasnowski P, Lanati LA, Stariolo R, Kitron U. Strong host-feeding Preferences of the vector Triatoma infestans modified by vector density: Implications for the Epidemiology of Chagas Disease. Plos Negl Trop Dis 2009; 3:447.

15. Guarneri AA, Pereira MH, Diotaiuti L. Influence of the blood meal source on the development of Triatoma infestans, Triatoma brasiliensis, Triatoma sordida and Triatoma pseudomaculata (Heteroptera: Reduviidae). J Med Entomol 2000; 37:373-379.

16. Daflon-Teixeira NF, Carvalho-Costa FA, Chiang RG, Lima MM. Influence of blood meal and mating in reproduction patterns of Triatoma brasiliensis females (Hemiptera: Reduviidae) under laboratory conditions. Mem Inst Oswaldo Cruz 2009; 104:1031-1034.

17. Aldana E, Jácome D, Lizano E. Efecto de la alternación de fuentes sanguíneas sobre la fecundidad y la fertilidad de Rhodnius prolixus Stål (Heteroptera: Reduviidae). Entomo Brasilis 2009; 2:17-23.

18. Zeledón R, Rabinovich JE. Chagas disease: an ecological appraisal with special emphasis on its insect vectors. Ann Rev Entomol 1981; 26:101133.

19. Cabello DR, Lizano E, Valderrama A. Efecto de la frecuencia alimentaria sobre algunos parámetros poblacionales de Rhodnius neivai. Mem Inst Oswaldo Cruz 1988; 83:441-446.

20. Davey KG. The interaction of feeding and mating in the hormonal control of egg production in Rhodnius prolixus. J Insect Physiol 2007; 57:208-215.

21. Zeledón R, Guardia VM, Zúñiga A, Swartzwelder JC. Biology and ethology of Triatoma dimidiata (Latreille, 1811). I: Life cycle, amount of blood ingested, resistence to starvation and size of adults. J Med Entomol $1970 ; 7: 313-319$.

22. Perondini ALP, Costa MJ, Brasileiro VLF. Biologia do Triatoma brasiliensis. II- Observações sobre a autogenia. Rev Saude Publica 1975; 9:363-370.

23. Noriega FG. Autogeny in three species of Triatominae: Rhodnius prolixus, Triatoma rubrovaria and Triatoma infestans (Hemiptera: Reduviidae) J Med Entomol 1992; 29:273-277.

24. Carrizo SA. Efecto del ayuno sobre la capacidad reproductiva de Triatoma patagonica Del Ponte, 1929 (Hemiptera, Reduviidae) [Thesis]. [Córdoba, Argentina]. Facultad Ciencias Exactas Físicas y Naturales, Universidad Nacional de Córdoba; 2003. 30 p.

25. Abalos JW. Sobre la importancia epidemiológica de Triatoma patagonica. Rev Fac Med Tucumán 1959; 2:19-25.

26. Crocco LB, Catalá SS. Feeding and defaecation patterns in Triatoma sordida. Mem Inst Oswaldo Cruz 1996; 91:409-413.

27. Catalá S, Giojalas L, Crocco L. Temperature effect upon blood consumption in Triatoma infestans. Mem Inst Oswaldo Cruz 1992; 87:473-476.

28. Catalá de Montenegro SC. Determinación de las reservas alimenticias en Triatoma infestans Klug, 1834 (Hemiptera, Reduviidae) en base a caracteres externos. I. Adultos. Phys Secc C 1983; 41:159-167.

29. Nattero J, Rodríguez C, Crocco L. Effects of blood meal source on food resource use and reproduction in Triatoma patagonica Del Ponte (Hemiptera: Reduviidae). J Vector Ecol 2013; 38:127-133.

30. Chiang RG, Chiang JA. Fecundity of the blood-feeding insect Rhodnius prolixus increases in successive periods of egg production. Cell Mol Life Sci 1995; 5:289-292.

31. Asín S, Crocco de Ayerbe LB. Influence of mating on ovarian follicle development in Triatoma infestans (Klug 1834). Mem Inst Oswaldo Cruz 1992; 87:369-374.

32. Lima MM, Jurberg P, Almeida JR. Behavior of triatomines (Hemiptera, Reduviidae) vectors of Chagas disease. III. Influence of the number of matings on the fecundity and fertility of Panstrongylus megistus (Burm, $1835)$ in the laboratory. Mem Inst Oswaldo Cruz 1987; 82:37-41.

33. Rabinovich JE. Vital statistics of Triatominae (Hemiptera: Reduviidae) under laboratory conditions. I. Triatoma infestans Klug. J Med Entomol 1972; 9:351-370.

34. Juárez E, Castro Silva EP. Comportamento do Triatoma sordida em condições de laboratório. Rev Saude Publica 1982; 16:1-36. 
35. Bar ME, Oscherov EB, Damborsky MP. Presencia de Triatoma sordida Stål, 1859 en ecotopos urbanos de la ciudad de Corrientes, Argentina. Rev Saude Publica 1983; 27:117-122.

36. Tolesano JE, Araújo MFS, Chieffi PP, Valentin AM, Ribeiro SS. Variavéis relacionadas ao desenvolvimiento de Triatoma infestans Klug, 1934 em condições de laboratorio. Efeitos da manipulação na sobrevivencia e na fertilidade. Rev Inst Adolfo Lutz 1984; 44:81-86.
37. Arévalo A, Carranza J, Guhl F, Clavijo J, Vallejo G. Comparación del ciclo de vida de Rhodnius colombiensis Moreno, (Jurberg \& Galvao, 1999) y Rhodnius prolixus (Stål, 1872) (Hemiptera, Reduviidae, Triatominae) en condiciones de laboratorio. Biomédica 2007; 27:119-129. 